Volume 9

Issue 2 Time, Movement, and Space: Genocide

Studies and Indigenous Peoples

Article 16

$10-2015$

\title{
Film Review: The Look of Silence
}

Nicole Rafter

Northeastern University

Follow this and additional works at: https://digitalcommons.usf.edu/gsp

\section{Recommended Citation}

Rafter, Nicole (2015) "Film Review: The Look of Silence," Genocide Studies and Prevention: An

International Journal: Vol. 9: Iss. 2: 135-137.

DOI:

http://dx.doi.org/10.5038/1911-9933.9.2.1357

Available at: https://digitalcommons.usf.edu/gsp/vol9/iss2/16

This Film Review is brought to you for free and open access by the Open Access Journals at Digital Commons @ University of South Florida. It has been accepted for inclusion in Genocide Studies and Prevention: An International Journal by an authorized editor of Digital Commons @ University of South Florida. For more information, please contact digitalcommons@usf.edu. 
Film Review: The Look of Silence

\author{
Nicole Rafter \\ Northeastern University \\ Boston, Massachusetts, USA \\ The Look of Silence - Film Review
Director: Joshua Oppenheimer
Denmark/Finland/Indonesia/Norway/UK, 2014
Reviewed by Nicole Rafter
Northeastern University
Boston, United States
}

Every genocide needs at least one excellent film to establish a record and keep its memory alive. For the Indonesian genocide of 1965-66, that film is Joshua Oppenheimer's The Act of Killing (2012), a stunning documentary about genocidists who acted out their fantasies of being movie stars while killing, and then reenacted their grotesque fantasies fifty years later for Oppenheimer's camera.

Now Oppenheimer has released a second movie about the Indonesian genocide, The Look of Silence, in which the point of view is that of a victim's family. This film, while less of a milestone for documentary cinema, is just as compelling and necessary. The two films were conceived as companion pieces, one about perpetrators and the past, the other about victims and the present. ${ }^{1}$

Some context: The Indonesian killings of 1965-66 were never deemed a genocide by an international court and in fact do not fit the United Nations Convention for the Prevention and Punishment of the Crime of Genocide (UNGC) definition of genocide as an effort to destroy a national, ethnic, racial, or religious group, as such. In this case, the targeted group was politicalthe Indonesian Communist party, the largest Communist party in the world outside the Soviet Union and China. The Communists' strength and ideology threatened both the country's large Muslim population and the conservatives who ran the army. The genocide began when Major General Suharto came to power by hijacking an attempted coup by other army officers. Suharto consolidated his position as the country's new leader by killing around 500,000 people. ${ }^{2}$ In addition, hundreds of thousands of political prisoners were incarcerated for years of being subjected to torture and rape, and the families of murdered Communists were ostracized for generations.

That these events do not precisely fit the UNGC's definition suggests that the UN's definition should be expanded to cover political groups as well. If by genocide we mean an effort to exterminate a group, then the type of group should not matter. Moreover, the processes by which groups are defined are always political; thus the UNGC's definition is too narrow.

To return to the film: The Look of Silence is organized around the quest of Adi, a middle-aged optician, to discover the killers of his brother Ramli, who died in the genocide two years before Adi was born. Ramli's case had become iconic on the Indonesian island of North Sumatra because there were witnesses who could tell parts of the story. Adi was encouraged to look deeper into the murders by studying footage of Oppenheimer's The Act of Killing, shot between 2003 and 2005.

Before that film was released, Oppenheimer returned to North Sumatra to film Adi's story. "Rather than pick up where we left off in 2003," Oppenheimer writes, "Adi wanted to meet the men involved with his brother's murder. By introducing himself to them as the brother of their victim, he hoped they would be forced to acknowledge that they killed human beings" instead of gleefully denying responsibility, as they do in the earlier film. ${ }^{3}$

Adi hits upon an ingenious method of getting the killers to talk - he informs them it is time to test their eyes. He goes into their homes with a portable device for trying out new lenses-metal frames into which various lenses can be slipped. And then he starts asking questions. While checking the glasses prescription of a wealthy community leader, for example, Adi asks about his work during "the mass killing here," later explaining that his eldest brother was killed "because 
you commanded the killings." ("It wasn't really me," the man responds; we had commanders above us, "so you can't say I'm responsible.")

Adi's stratagem gives the film its emblematic image, that of eyes peering out of the metal device, a fantastical contraption with colored circles and tabs jutting out like little rays. This image, which appears several times during the film, is the only one to reach the level of grotesquerie found in The Act of Killing. The Indonesians who watch Adi (and the camera) through the optometrist's device are all perpetrators, thus contributing their own set of meanings to the title: They are those who look without telling, or at least without telling much.

Denial is but one of the barriers Adi encounters during his search; another is threats to his life. A powerful legislator warns him, "If you keep making an issue of the past, it will definitely happen again." "Be careful," Adi's elderly mother urges. "They could slip poison in your drink. They'll send thugs to rip you apart. . . Just leave it." "I set out to do something unprecedented," Oppenheimer writes, make a film where victims confront perpetrators while the perpetrators still hold power. The confrontations were dangerous. When we'd meet more powerful perpetrators, we would bring only Adi and me and my Danish crew... Adi would come with no ID card. We would empty all numbers from our telephones and bring a second car we could switch to minutes after leaving, making it harder for the perpetrators to send police or thugs to follow us." 4

None of those who appear in the film is named in the credits. The co-director is listed as Anonymous, as are the many assistant directors, drivers, and others who helped make The Look of Silence. The threats extended to all involved.

One of the film's most important messages is how powerful Suharto's anti-Communist ideology remains, even though Suharto resigned under pressure in 1998 and the grip of the police state is weakening. We see a school teacher feeding propaganda to young children, including Adi's son. We watch Adi interview one of the leaders of the Snake River massacre in which Ramli perished; today he is now a prominent politician. We realize that genocides, far from ending with the last bullet or final knife slash, persist for generations, causing harm in other ways.

Throughout, Oppenheimer intercuts footage taken earlier, during shooting for The Act of Killing but not included in that film, with shots of Adi in the present. The former footage is differentiated by being shown on a television screen; it mainly depicts two killers reenacting the death of Ramli -and cackling over their deeds. ("Rip off his penis" one says during the reenactment; "I brought a knife to make it more authentic.") Then the two killers demonstrate the dismemberments, executions, and decapitations of the massacre's victims, telling how they threw the body parts into river. Later they joke about polluting the river. One recalls that while they were busy with "the people's struggle" -the massacre- the military waited on the road "to protect their image ... but everyone knows the army was behind it."

These scenes projected on the television screen are intercut with images of Adi, watching them, his handsome face immobile. Through the reenactment, he comes close to watching the actual death of his brother. His look, deeply absorbed but undemonstrative, is also the look of silence.

Footage of Adi interviewing perpetrators, a third strand of imagery, is intercut with the other two -the scenes projected on the television and images of Adi watching them. The perpetrator interviews show him circling in on the truth about the deaths of his brother and others killed at Snake River. One man being fitted for new glasses recalls that he and his friends drank the victims' blood to avoid going crazy. Staying steady, Adi slips a new lens into the device and asks, "Is this more clear?" "A bit blurry. . . Both salty and sweet, human blood." From this same perpetrator Adi learns that "If you cut off a woman's breast, it looks like a coconut milk filter. Full of holes."

In his Director's Notes, Oppenheimer writes that

The Look of Silence is, I hope, a poem about a silence born of terror--a poem about the necessity of breaking that silence, but also about the trauma that comes when silence is broken. Maybe the film is a monument to silence, a reminder that although we want to move on, look away and think of other things, nothing will make whole what has been broken. Nothing will wake the dead. We must stop, acknowledge the lives destroyed, strain to listen to the silence that follows. 
For the director, too, making this film must in some ways have been a look of silence, an act of wordlessly watching people come to terms with the politics of silence.

A fourth and final strand of footage depicts Adi's family-his aged and senile father, who cannot remember Ramli; his mother, still grieving over Ramli's loss although nearly half-a-century has passed; his wife, who worries about Adi's safety; and his two children. These tender and caring scenes are subtle reminders that the victims of genocide include many others in addition to those who died.

This theme also enables the film to end on a note of hope. Throughout we have occasionally seen images of little dancing pods-butterfly chrysalides, wiggling. In one of the final scenes, Adi's mother holds some of the pods in her hand, watching their delicate life struggle into being. "I can't see you," she says to them. "Are you there? Come out."

If The Look of Silence is not as overwhelming as The Act of Killing, that is because its organization around a quest is more traditional, less outré and freakish, than the latter's depictions of unrepentant genocidists still posing as movie stars on a killing binge. Moreover, a film about the aftermath of victimization is almost by definition less shocking than one that shows killings themselves, albeit in reenactment.

The Look of Silence closely parallels another genocide film, Enemies of the People (Rob Lemkin, Thet Sambath, 2009), a 2009 documentary about the Cambodian genocide in which filmmaker Thet Sambath persuades former Khmer Rouge cadres to demonstrate how they killed. Thet Sambath, too, lost a brother to genocide, but his quest is broader: he wants to understand the genocide more generally. His film is in many ways more engaging, partly because he himself is more actively engaged in the quest and partly because his character is more fully developed than that of Adi. Moreover, he manages to bag the biggest game of all: Brother Number Two, Nuon Chea, the Khmer Rouge's main ideologist. Thet Sambath befriends Nuon Chea while he is still living in the countryside, before he is put on trial, and he shoots extensive footage of their relationship.

But The Look of Silence - which has won numerous awards, including the Grand Jury prize at the 2014 Venice Film Festival-bears vivid witness to the devastation wrought by the Indonesian genocide. And it is extraordinary, as Oppenheimer points out, for a film to show a victim confronting perpetrators while they are still in power.

Title of the Film: The Look of Silence; Director: Joshua Oppenheimer; Co-Director: Anonymous; Producers: Signe Byrge Sørensen, Anonymous, Anne Köhncke, Werner Herzog, Errol Morris; With: Adi Rukun; Cinematography: Lars Skree; Film Editor: Nils Pagh Andersen; Countries: Denmark/ Finland/Indonesia/Norway/UK; Year of Release: 2014; Production Company: Final Cut for Real. Duration: 103 minutes.

NOTE: The company Film Platform has exclusive educational rights for The Look of Silence and will be selling DVDs and licensing academic screenings from 1 September 2015. More information can be found at http://filmplatform.net.

\section{Endnotes}

1 http://thelookofsilence.com (Director's Notes).

2 The film gives the number killed as 1 million, but that figure has now been revised downward to 500,000, while estimates of the number detained as political prisoners have been revised upward, to between 500,000 and 1 million or more prisoners held between 1965 and the early 1970s.

3 http://thelookofsilence.com (Director's Notes).

4 http://thelookofsilence.com (Director's Notes). 